\begin{tabular}{l} 
RCCS \\
\hline Annual Review
\end{tabular}

\section{RCCS Annual Review}

A selection from the Portuguese journal Revista Crítica de Ciências Sociais

$7 \mid 2015$

Issue no. 7

\title{
Middle-class Rebellions? Precarious Employment and Social Movements in Portugal and Brazil (2011-2013)
}

\section{Elísio Estanque}

Translator. João Paulo Moreira

\section{OpenEdition}

\section{Journals}

Electronic version

URL: http://journals.openedition.org/rccsar/592

DOI: $10.4000 /$ rccsar.592

ISSN: 1647-3175

\section{Publisher}

Centro de Estudos Sociais da Universidade de Coimbra

\section{Electronic reference}

Elísio Estanque, « Middle-class Rebellions? Precarious Employment and Social Movements in Portugal and Brazil (2011-2013)», RCCS Annual Review [Online], 7 | 2015, Online since 01 October 2015, connection on 30 April 2019. URL : http://journals.openedition.org/rccsar/592 ; DOI : 10.4000/ rccsar.592 


\section{Elísio Estanque}

School of Economics and Centre for Social Studies, University of Coimbra, Portugal

\section{Middle-class Rebellions? Precarious Employment and Social Movements in Portugal and Brazil (2011-2013)*}

This text centers on the demonstrations and protest movements that have emerged over the past three years, with a particular focus on Portugal and Brazil. The main argument is based on the hypothesis that they involve social dynamics and tensions that reflect a middle class drive in which youth and precarious employment play a key role. It presents data and empirical evidence on inequality in Portugal in order to reveal the nature of the main movements as protests mobilized against the suppression of rights and the undermining of working conditions. The situation in Brazil is examined in the light of the recomposition of working class conditions, taking into account the constraints and uncertainties of the Brazilian model of development. It also analyzes the social composition of the protesters, on the basis of street surveys carried out during this period.

Keywords: middle class; social protest; social inequality; social movements; precarization of labor.

\section{Introduction}

This text centers on recent demonstrations and protest movements, particularly in Portugal and Brazil, its main hypothesis being that they involve social dynamics and tensions that reflect a middle-class drive in which youth and precarious employment play a key role. Its approach aims to move beyond established theories of social movements in the Western world. It thus seeks to situate this entire phenomenon in its broader socio-economic context - a context of crisis to boot - in order to discuss, on the one hand, the way in which the fragmentation of paid work and rising precarious employment have contributed to the increase in inequalities, and on the other hand the way in which the ineffectiveness of institutions and public policies played a decisive role in generating the kind of social conflict that eventually led to social rebellion in recent years.

Let me say right out that what I offer here is not sociological 'research' per se, but rather some reflections in an essayistic vein whereby I attempt to make use of a number of data and empirical elements (some of them from indirect sources, others coming from direct observation) in order to explore an explanatory hypothesis that falls outside the accustomed canons of academia. I am therefore quite aware of the controversial nature of the present article and I even grant that this might be its greatest virtue, inasmuch as it may contribute

\footnotetext{
* Article published in Portuguese in RCCS 103 (May 2014). DOI: 10.4000/rccs.5540
} 
to force the social sciences out of their 'ghetto' in order to address a wider audience. With that in mind, I seek to contribute to a deconstruction of the concept of "middle class" and its accompanying train of connotations having to do with passivity, individualism and unthinking adherence to the "bourgeois order," by placing a special emphasis on the segmentations currently observable within the working class and materialized in the emergence of precarious, unstable, qualified new sectors of the workforce. Added to this is a concern with the need for a conceptual and analytical updating of the most recent forms of collective action such as those of the latest cycle of social movements in which the instances mentioned in this article are included.

It is therefore the purpose of the present essay to point to what is new about these occurrences and show the transformative potential of those novel aspects. In short, we need an answer to the following questions: (1) what are the main social groups on which such movements are based, i.e., who exactly is participating in them?; and (2) what is the import of the change brought about by these movements on society at large, both during their most intense moments and in their aftermath?

Resistance to the status quo, i.e., to an economic and political order which not only failed to meet expectations but also threatened or undermined people's rights and blocked opportunities, seems to reflect common concerns on both sides of the Atlantic. By unveiling existing connections with the world of labor and the impoverishment of large social groups an impoverishment spurred, in the case of Portugal, by the austerity policies inflicted on occupational groups that had aspired to a lifestyle similar to that of the (salaried) urban middle class - it is my intent to stress the transformative potential of rebellion itself. I argue that the sectors of the population involved in these demonstrations have some kind of connection with consumption patterns that characterize the intermediate segments of society, even though this is more the case at the subjective than at the socio-economic level, which in any event seems to be marked by instability and precariousness. The assumption here is that those social segments that took part in the protests are struggling with rapid changes relating to status and to consumption patterns, which in turn are also linked to (either endangered or fragile) labor rights and a deep sense of frustration and injustice. The relationship with the changing labor market, the impacts of the global economy and of the growing commodification of social life, as well as the technological mutations and their ramifications in today's communication networks, are among some the factors to be taken 
into account in my description of the similarities and differences between the two contexts under analysis.

\section{A Cycle of Global Protest - Revolution and Action}

Some of the old approaches to the new social movements (NSM), dating from the 1960s and 1970s, have obviously lost their currency. Alain Touraine's classic definition $(1985 ; 2006)$ of what a social movement is, with its well known precepts - identity (who are we?), opposition (who do we fight against?) and totality (what sort of society are we fighting for?) - will hardly do to explain today's mobilizations. Identities tend to be more and more disjointed and volatile, even though one could argue that the very ardor of collective action is bound to instill in those who take part in it a certain sense of communion, albeit an elusive and fleeting one. Even if an opponent does exist (in accordance with the opposition principle), the adversarial figure in these mobilizations is not always easy to pin down. In some cases they confront tyrannical regimes and their top representatives, focusing on the dictator as the embodiment of what they fight against. Other times the opponent is an abstraction (capitalism) or comes in the shape of a situated power (city hall, a certain cabinet minister, the federal government) which may eventually change and lead to other, more remote opponents (the government, the IMF, the European Commission, etc.). Finally, with regard to the totality principle, which pointed to an alternative model of society (e.g., socialism), we know too well that this distant goal is far from being the unifying element of social movements in the $21^{\text {st }}$ century. Until a new utopia grows strong enough to offer itself as an alternative, the uncertainties and ambiguities of these movements will tend to persist (Cohen and Arato, 1994; Laclau 1996; Melucci, 2001; Santos, 2003).

In recent decades the question of an alternative has acquired a new meaning. In other words, people no longer rally in the name of the future. They do it to reject a humiliating past or a degrading present (Arcary, 2013). Even more significant than the past (whether glorious or miserable) is the fact that the majority of people loathe their present predicament and are beginning to realistically entertain the thought of changing their lives and facing the unknown: the notion that "it can't possibly get any worse" may turn out to have a mobilizing effect. As a renowned expert in the matter put it, "No enlightened, moderately intelligent observer could survey the state of the planet and conclude that it 
could be put to rights without a thoroughgoing transformation" (Eagleton, 2003: 180). Another contemporary intellectual, Slavoj Žižek, said recently that

the difference between a reformist and a revolutionary period [is that] in a reformist period, global revolution remains a dream which, if it does anything, merely lends weight to attempts to change things locally; in a revolutionary period, it becomes clear that nothing will improve without radical global change. (Žižek, 2013: 101)

One should not confuse the social uprisings under analysis with revolutions in the sense described by Žižek, although we know that in some cases, as in the so-called Arab Spring (Tunisia, Egypt, Libya), radical changes did occur, with governments and regimes falling apart because of the magnitude and intensity of the street demonstrations. ${ }^{1}$ In view of the configuration and particularities of some of these uprisings, and given the pressure they put on governments and institutions, there is arguably a "revolutionary" potential in them, although their fuzzy nature and lack of an "alternative" or some sort of ideological direction point to open-ended (i.e., either progressive or reactionary) outcomes. Information technology and the new social networks in particular proved to be the decisive ingredient in this new cycle of social protest.

\section{The Middle Class: Between Individualism and Precariousness}

In spite of all the controversy and the theoretical inaccuracies inherent in the phrase "the middle class," there is a heuristic potential in it. In order to bring it out we have to look at the origins of the concept, searching for the reasons why it came to be so deeply rooted in common parlance. A recent article by Ezekiel Adamovsky (2013) shows that the phrase draws on an old popular metaphor based on the premise that the physical world is invariably organized in terms of a "higher," an "intermediate" and a "lower" element. This is what led to the dissemination of a mind map based on the moral principle that virtue lies in the middle, i.e., the intermediate position corresponds to the locus of the right measure, of moderation and virtue, as opposed to extremes (which, in the case at hand, stand for destitution on the one hand, and excessive wealth on the other). Under Europe's ancient

\footnotetext{
${ }^{1}$ This could also be the case (although a more controversial one, given the particular circumstances involved) in the recent events in Ukraine, from November 2013 through February 2014. At the time, President Yanukovich's government was overthrown after a fierce, determined popular opposition that lasted about three months and led to the occupation, by demonstrators, of Maidan Square, the main square of the Ukrainian capital, Kiev. The incidents resulted in dozens of deaths, the government's resignation, the President's escape and the appointment of an interim government (while the country as a whole suffered retaliation from Russia and was on the brink of division and civil war).
} 
liberal tradition, the idea of civilization and progress became increasingly associated with a given standard of living and culture, as part of a process of historical evolution that was to bring the middle class to a leading position in the course of the $20^{\text {th }}$ century. The middle class was thus labeled "the motor of history" (in spite of, or in close connection with, the "class struggle"), at least in the eyes of European liberalism and social democracy, even if the US stuck to the old $19^{\text {th }}$ century motto of individual entrepreneurism (and meritocracy) as the means to set the Tocquevillian middle class on its path to the Eldorado.

On the other hand, the debate around the concept "middle class" calls for a dynamic approach, while acknowledging that its conceptualizations have been articulated in many different ways by social scientists throughout the $20^{\text {th }}$ century. Instead of an "essentialist" understanding (typically based on the notion of homogeneity) derived from the traditional class struggle dichotomy, our focus should be on the internal tensions and the segmentation processes dividing groups and subgroups bent on monopolizing resources, power and social status, though keeping in mind that such processes tend to unfold as part of the conflict between capital and labor. ${ }^{2}$ Social conflict does not depend on the Marxian criterion of "the place in the social relations of production" alone (where the ownership of private property and surplus transfer are the defining factors of the relationships between the main social classes), as there are also status and lifestyle conflicts resulting from the logics of usurpation and distinction that persist within the middle class. This is one of the aspects where the Marxist and Weberian legacies can be mutually enriching (Parkin, 1979; Bourdieu, 1979; Eder, 2001; Burawoy, 2009).

We are all familiar with the historical role of the labor movement and trade unions - as well as the promises of "Soviet socialism" and the Cold War climate - in making possible the "historic compromise" (between labor and capital) that paved the way for Europe's social policies - the welfare state - in the second half of the $20^{\text {th }}$ century and thence for the

\footnotetext{
${ }^{2}$ My aim at present is not to offer an in-depth discussion of the concept of "social class," which in Karl Marx's classic definition relates to the social division of labor and the control of property under the capitalist mode of production: "The owners merely of labor-power, owners of capital, and land-owners, whose respective sources of income are wages, profit and ground-rent, in other words, wage laborers, capitalists and land-owners, constitute then three big classes of modern society based upon the capitalist mode of production" (Capital, Vol. 3, Ch. 52). According to V. I. Lenin, social classes are "large groups of people differing from each other by the place they occupy in a historically determined system of social production, by their relation (in most cases fixed and formulated by law) to the means of production, by their role in the social organization of labor, and, consequently, by the dimensions of the share of social wealth of which they dispose and the mode of acquiring it. Classes are groups of men in which one can appropriate the work of the other as a result of the difference of place they hold in a given system of social economy" (Collected Works, Vol. 29).
} 
expansion of the middle class (Erikson \& Goldthorpe, 1992; Esping-Andersen, 1996). As a matter of fact, the growth of this particular category in European societies is not, nor has it ever been, the immediate result of an alleged "meritocracy," but rather the outcome of (union-led) dogged struggles and negotiations carried out by the new skilled segments of the working class, whose aspirations included more rights, purchasing power, careers and social protection. These strata are formed by "intermediate" working class categories that owe the consolidation of their status to social struggle, and therefore no longer correspond to the "established," would-be elitist middle class that did nothing but reap the benefits of the material inheritance or the business world handed down from their ancestors. Although benefitting from a process that "elevated" them to a higher status, after about six decades the children and grandchildren of the postwar working class are now largely threatened by impoverishment and find themselves in an ambivalent, unbalanced situation, in that they are highly qualified and possess a solid educational capital but their income is low and still declining. This has led to the deterioration of their status (Estanque, 2012) and to a radicalization of their subjectivities and political positioning. The old service class (Goldthorpe \& Erikson, 1992) thus tends to turn into a rebel class, especially as far as its incipient sectors are concerned. That is the case of young people, who tend to feel deeply ambivalent by nature, given that they are still at an unconsolidated, vulnerable stage in terms of their personal history and class habitus (Pais, 1990). ${ }^{3}$

Some authors have linked the recent transformations in the labor market to the emergence of the precariat (Standing, 2013), a category that includes significant sectors of the salaried middle class whose labor has become "insecure and unstable, so that it is associated with casualisation, informalisation, agency labour, part-time labour, phoney selfemployment and the new mass phenomenon of crowd-labour" (Standing, 2014). ${ }^{4}$ There is no consensus about these conceptualizations in today's debates. Although admitting the possibility that the precariat is a class-in-the-making, Standing claims that there is a world of

\footnotetext{
${ }^{3}$ See, in addition to José Machado Pais, Pierre Bourdieu's (1992) seminal "La 'jeunesse' n'est qu'un mot," Questions of Sociologie. Paris: Editions Minuit, 143-154 [orig. edition, 1984].

${ }^{4}$ Those who have been denied the conditions enjoyed by the traditional worker: i) access to jobs with stable wages; ii) assurance of an employment contract; iii) career security and opportunities; iv) protection against work-related hazards and accidents; v) access to vocational education and training; vi) assurance of stable, progressive wages; vii) assurance of collective or union representation (Standing, 2013: 27-28). "Flexi-workers" or "Generation Y" (born after 1980) are just some of the labels for this new legion of precarious workers whose new language - e-mail, SMS, Facebook, etc. - makes them sound at times like a true "Cyber-Proletariat" (Huws, 2003).
} 
difference between this vulnerable workforce and what he terms "the salariat" (i.e., the old category of "sheltered" industrial workers). Moreover, Standing accepts the fact that the vulnerability, instability and volatility of labor forms and relations are irreversible. He sees them as "an imperative in the global labor process" and goes so far as to suggest a "paradise"-type scenario characterized by the expansion of the current model of labor flexibility and commodification, not as a result of trade union action, but thanks to "a new type of collective body" willing to "take up the challenge of "collaborative bargaining"" (Standing, 2013: 252). Of course, this view is disputed by those approaches that are far more critical of global capitalism.

For Ursula Huwz (2003), Ricardo Antunes (2013) and Ruy Braga (2012), among others, the new segmentation and recomposition of labor are the main driving force behind the new global social struggles, given their implications in terms of the deterioration of living conditions and growing structural impoverishment, which in turn are an element of - and a catalyst for - the very dynamics of capitalism. The situation in Brazil has its own specificities, with protests arising from a combination of many different factors and staging radical actions by cells of politicized activists alongside spontaneous demonstrations by some segments of the disaffected middle class. At a broader level, what we have at present is a huge fragmentation and metamorphosis of the working class, in the wake of global capitalism's metabolism. In short, both in Portugal and Brazil the recent wave of uprisings led various sectors of those subaltern, precarious groups to coalesce with other segments of the workforce, epitomizing the new paradigm of labor and class struggle. As mentioned earlier, however, the alliances between these two major groupings are themselves precarious and sporadic (or simply non-existent). Lacking well-defined goals and leadership, street actions thus tend to be dictated by as yet latent impulses and anxieties rather than by clearly established policies. The notions of latency and "drive" ${ }^{5}$ can therefore be adjusted to collective dynamics which, their political impact notwithstanding, also partake of crowd logics and behavior.

\footnotetext{
${ }^{5}$ In its biological sense, the word "latency" designates an organism's state of repose, where vital functions are still hardly visible prior to its becoming fully active. According to Merton's distinction between manifest and latent functions, the latter are defined as undesired or unintended. As to the notion of "drive," with its Freudian overtones, it signifies the instinctive, more or less conscious tendency that stimulates and motivates a subject to act. Add to these notions Bourdieu's concept of habitus, and we have at our disposal a number of concepts that make it easier to accept the existence of a "semiconscious" area of collective action operating in the half-light of the more spontaneous, inorganic social movements, where repressed desires as well as unmet needs and expectations tend to lie hidden and exposed at one and the same time.
} 
The pronounced mobility, volatility and instability of the workers that make up the precariat set them worlds apart from the 'old' $19^{\text {th }}$ century English proletariat studied by F. Engels (2009 [1845]) and E. P. Thompson (1966 [1963]), especially when we consider its experiences and forms of conviviality, which gave rise to a culture of resistance and a working class consciousness in the context of the struggle against emerging capitalism. Hence, even while acknowledging the structural nature of the precarious condition that marks the $21^{\text {st }}$ century, we need to pay attention to the profound reconfiguration of working conditions if we are to understand the disconnect between the present composition of the working class (both more qualified and more precarious) and its reflection in the sociopolitical arena.

In order to understand these new trends we must look at the recent past. With the end of Fordism, once the thirty glorious years were over, it became evident for Western Europe that the promise of "meritocracy"-based, working class "upward mobility" was a fallacy. In fact, the social struggles that marked the $20^{\text {th }}$ century were not caused by the workers' "vanguard" alone, but also by the "beneficiaries" of the welfare state, including a host of new socio-professional categories (teachers, doctors, civil service officials, etc.). In his classic Middle Class Radicalism (1968), Frank Parkin described a variety of groups within the middle class, stressing the importance of the educated middle class ${ }^{6}$ for its role in the environmental movement of the late 1960s (Parkin, 1968: 177). Although post-68 Western capitalism proved capable of regenerating itself, such movements opened the way to new values, new repertoires, as well as innovative dimensions and forms of collective action (Eder, 2001; Boltanski and Chiapello, 2001; Estanque, 2012).

But one must not overlook the specificities of each individual country. As we know, Portugal had to deal with the consequences of late industrialization and democratization, whereas Brazil was affected by different historical and sociocultural conditions, having to do with the legacy of colonialism. That is why, just like in the past, present discussions regarding

\footnotetext{
${ }^{6}$ Frank Parkin claims that although educational capital is a relevant factor, we need to consider two different segments: on the one hand, we have professional employees engaged in business and commerce (e.g., in insurance, banking, marketing, sales, as technical executives or in managerial positions in private companies, etc.); on the other hand, there are those working in activities that have to do with welfare, education and creative occupations (such as social service, health care, schools, journalism, science-related professions, etc.). While the latter focus on the notion of service to the community, improvement of the human condition, and expressive or creative skills, the former tend to be framed by business world values and influenced by an excessive concern with profit and efficiency, whose rewards are mainly of a material or monetary nature (Parkin, 1968: 180).
} 
class structure and the whole Brazilian middle class controversy call for a different set of references. First of all, the colonial heritage and the historical presence of slavery have left an indelible imprint. Then there was the late emergence of the established middle class, ${ }^{7}$ which benefitted directly from the central government's policies, particularly during the Vargas presidency and Brazil's so-called "economic miracle" (1968-1973). This privileged segment of the middle and upper-middle classes (particularly in and around the city of São Paulo) is heir to a social status and a conservative subjectivity that tend to "naturalize" its (either real or imaginary) position next to the country's elite. That legacy is the reason for its biased attitude toward the new emerging segments and the social strata formed by the very poor and the excluded, who in the end are the main victims of stigmatization, i.e., of a "class racism" that seems shocking to anyone visiting places like downtown São Paulo even today (Guimarães, 2002; Santos, 2004; Souza, 2010).

This means that we are talking about just one "subcategory" of the middle class, characterized by high economic capital but poor cultural and educational capital, which can be contrasted with the new, emerging "subcategories" with their high educational capital and low economic resources. A middle-class radicalism thus stands now in contradistinction to the old denunciations directed against the middle class, such as its inherent "individualism" and "embourgeoisement." Whereas in the past radicalism was articulated by the student and environmentalist movements of the 1960s (Barker, 2008; Estanque and Bebiano, 2007), in recent years it has manifested itself in an aggressive posture against the stifling of opportunities as well as in the pursuit of the still-incomplete welfare state and the eternal promise of economic development.

The typologies of class analysis are constantly being brought up to date, with new and interesting proposals being added to the list, namely those inspired by Weberian and Bourdieusian thought (Savage et al., 2013; Souza, 2010). ${ }^{8}$ But the heuristic value of the

\footnotetext{
${ }^{7}$ That which is commonly considered by academics as the middle class proper. As Marilena Chaui once famously (and heatedly) remarked, "The middle class is a political abomination, because it is fascist; an ethical abomination, because it is violent; and a cognitive abomination, because it is ignorant" (Panel discussion on "A Ascensão Conservadora em São Paulo" ["The Conservative Rise in São Paulo"], with André Singer and Vladimir Safatle, moderated by Ricardo Musse, USP 08.28.2012).

${ }^{8}$ I allude to the BBC's Great British Class Survey Experiment, a recent study based on a broad survey of social classes in the UK which used a sample of 161,400 respondents. The typology used by the authors includes seven categories, in which said "middle class" is divided according to several socio-economic and cultural variables (economic, social and cultural/educational capital) - in other words, where the concept of social class is addressed as a multidimensional construct comprising economic factors, symbolic elements as well as forms of social reproduction and cultural distinction.
} 
notion "middle class" calls for a richer framework of political and discursive processes, where certain sets of people can be grouped together with other sets, even if partaking of different socio-professional circumstances (Adamovsky, 2013: 48).

\section{Portugal and the Proletarianization of the Middle Class}

A study by Nuno Nunes (2013) drawing on the European Social Survey (ESS) and based on the class typology used by the ISCTE-IUL team ${ }^{9}$ analyzed the types of employment relationship cross-referenced with class categories in order to measure the degree of precarious employment with regard to the class variable. Nunes's findings show that the most vulnerable position as far as job stability is concerned is that of Routine Employees $(\mathrm{RE})^{10}$ (see Chart 1). Together with that of Professionals and Managers (PM), this category comprises qualified socio-economic segments that until only recently used to hold a stable position in the ranks of the salaried middle class. These are, in fact, the social groups whose statistical weight in relation to the employed Portuguese population as a whole had the highest gain over the last fifty years, going from $14.6 \%$ to $36.4 \%$ and from $2.6 \%$ to $22.5 \%$ between 1960 and 2011 (Carmo, 2013). As we can see, precarious work relationships (fixedterm contracts, phony self-employment and part-time work) affect not only the manual both industrial and agricultural - workers (categories "IW and AWL") but also "pettybourgeois professionals and managers" (PM) and "routine employees" (RE). It should be pointed out that, in relative terms, Portugal is the country where routine employees have been most severely hit by precariousness. ${ }^{11}$ This seems to indicate that the process that led to flexibilization and the fragmentation of work has hit not just the traditional segments of the manual labor force but also some sectors of the salaried middle-class and services workers, who have become a major target of corporate cost cuts.

\footnotetext{
${ }^{9}$ The team members include João Ferreira de Almeida, António Firmino da Costa and Fernando Luís Machado.

${ }^{10}$ This is in fact the category with the highest level of precarious employment, which ranges from fixed-term or part-time contracts to subcontracting through temporary employment agencies to phony self-employment.

${ }^{11}$ As to the relative weight of these categories - Entrepreneurs and Executives (EE), Professionals and Managers (PM), Routine Employees (RE), Industrial Workers (IW) and Agricultural Wage Laborers (AWL) -, the findings tell us that PMs went from 3.8\% of the employed working population in 1985 to $17.8 \%$ in 2009 , REs went from $36.1 \%$ in 1985 to $42.3 \%$ in 2009 , and the number of manual workers decreased from $56.4 \%$ to $33.7 \%$ during the same period; finally, with regard to EEs, who made up $1.5 \%$ of all workers in 1985, their number rose to $4.1 \%$ in 2009 . In terms of income distribution, the EE category (the one closest to the elite) has the highest income. This is a segment of the Portuguese population that acquired new skills and went through a significant process of feminization while also experiencing a considerable expansion. According to the same study, its monthly income had a substantial increase between the years 1995 and 2005, but then it fell until 2007, after which it remained stable (in 2009 the average monthly wage was 2,277.00 euros).
} 
It thus seems clear that in Portugal (just like in Estonia, Slovenia and Sweden) the "middle class" contains the strata where the most precarious work relationships are to be found. In other words, in recent years this segment - in close proximity to the precariat - has been virtually excluded from labor citizenship, as it is in no condition "to develop leisure and participate politically [...] because it lacks security" (Standing, 2009: 314).

\section{Chart 1. Labor Segmentation and Precarious Employment in the EU, by Class Category}

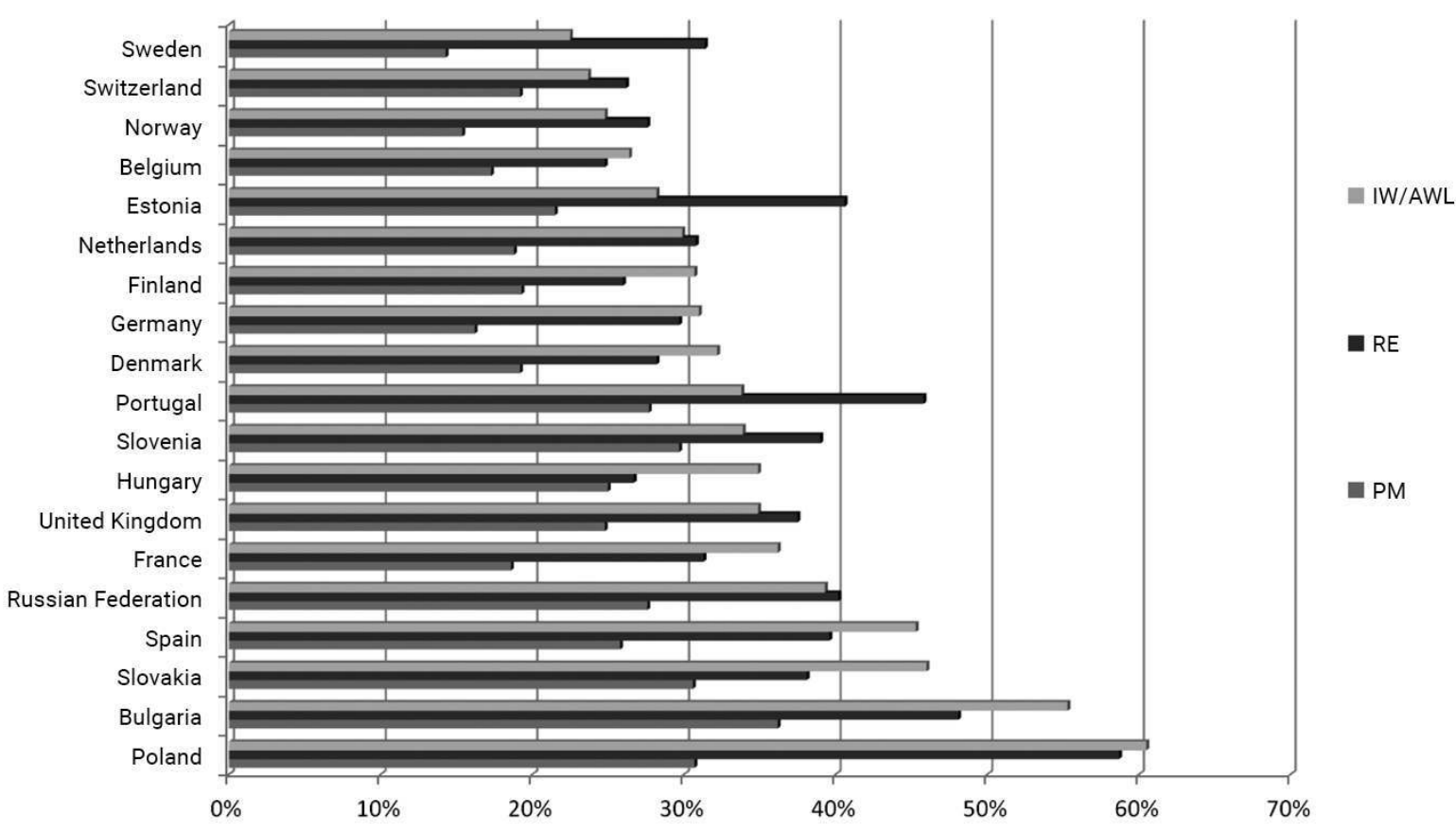

Source: ESS - European Social Survey (2006), in Nuno Nunes (2013: 127).

There is certainly a close connection between precarious employment and class provenance. To put it differently, the top-down "reform" imposed on the employment system impacts directly on social cohesion, with devastating consequences for labor conditions, the labor market and the lives of families and citizens. Hence the repercussions the austerity policies have had in terms of social inequalities since $2009,^{12}$ whereas the

\footnotetext{
${ }^{12}$ Some recent studies show that in the first decade of the $21^{\text {st }}$ century Portugal's inequality levels abated somewhat, although it still remained among the most unequal of all EU27 countries. Before the current crisis, real-wage fall was artificially compensated for by easy credit (pushed by the international financial system and low interest rates), a fact that allowed families to keep their lifestyles and comfort levels and to look positively toward the future (Carmo, 2013: 152-153). But other, more recent data show that Portugal's annual adult median income remains well below the average of European countries. In 2009 about 75\% of workers earned less than 12,625 euros per year (1052.1 euros per month), which caused Portugal to rank fourth in the list of countries with the greatest inequality and lowest wages in the Eurozone. In addition, the wages of the
} 
previous cycle had been marked by a positive evolution from the 1990s up to that year. If we use Ursula Dallinger's approach (2011), the distribution of the disposable money income per equivalent adult (household income) ${ }^{13}$ among the five quintiles of the population shows that the three middle quintiles (corresponding to the middle classes) saw their income grow from the 1970 s and again at the beginning of the new century. But then there was the 2009 reversal, when the crisis really struck Portugal at its worst: "in 2009-2010 the share of total income held by the $5 \%$ and $10 \%$ richest in Portugal rose by 0.8 and 0.6 percentage points, respectively" (Cantante, 2013: 137). By using the median wage ${ }^{14}$ - which in 2009 was as low as 741.00 euros (gross) - as reference, we may conclude, for example, that if we take the "middle class" to correspond to the layer in the $75-150 \%$ range of the median income, $51.4 \%$ of Portuguese wage earners fall within this segment (ibidem: 141).

As it happens, the restructuring of the employment system over the last decades had already revealed a high incidence of vulnerable workers, described as the new proletarians by some authors (Antunes, 2013). In the mid-1990s, a particular category - which in a previous study I had termed "proletarians" - comprised $46.5 \%$ of the Portuguese workforce, but by 2001 their number had dropped to 31\% (Estanque and Mendes, 1997; Estanque, 2003). This trend seems to confirm the notion that Portugal's middle class was fragile to begin with, which is what precipitated its decline (Estanque, 2012). From the 1990s, with economic globalization and the strengthening of neoliberalism, challenges to the European model and the welfare state began to be felt, and labor rights were the first to be affected. Rising unemployment, precarious contracts, tax increases, the freeze on civil servants' salaries and career promotions, the privatization of public services and utilities as well as public property, and cost-saving measures in such areas as health, education, science, etc., had long been denounced as a setback for the country's democratic achievements, and therefore opposed by a large part of the Portuguese even before they were struck by the crisis's most vicious phase. But social conflicts have become particularly severe in recent years. Between 2010 and 2012, there were 384 strikes in Portugal involving about 224,500

intermediate segments of society have decreased in recent years. Thus, the year 2009 brought a trend reversal, as that was the moment when the crisis and austerity took a dramatic turn for the worse (ibidem: 137).

${ }^{13}$ The criteria of the Eurostat statistics on income living conditions (EU-SILC) use the OECD Modified Equivalence Scale, which assigns a weight of 0.1 to the first adult (aged 14 or over) in the household, 0.5 to other adults than the household head, and 0.3 to children under 14 .

${ }^{14}$ That is, the middle value, with half the population earning less and the other half earning more than that amount. 
workers. ${ }^{15}$ Public discontent peaked during the rescue program, signed by the three traditional ruling parties - PS, PSD and CDS (Socialist, Social Democrat and Christian Democrat, respectively), which imposed an "austerity society" model on the Portuguese (Ferreira, 2012).

Although "non-organic" social movements tend to follow a logic that steers them away from trade unions, one cannot underestimate the importance of trade unionism in civil society's resistance to austerity policies (Estanque and Costa, 2011). The tension between these two worlds does not preclude the interconnections and cross-influences between them. Which is to say, the influence of the trade union field in terms of raising social awareness among citizens does not mean that there is conscious adherence to union proposals and forms of action on the part of the latter.

In fact, a recent study conducted by a team from the University of Lisbon's Institute of Social Sciences (ICS) indicated that few Portuguese feel themselves represented by either the trade unions (10\%) or the political parties (also 10\%), although social movements fared only marginally better (12\%) in terms of inspiring trust (Pinto et al., 2013). With regard to attitudes, the latest surveys have exposed a discrepancy between "importance" and "performance." That was the case with the recent findings of the 2012-2013 European Social Survey made available by the Institute of Social Sciences (ICS, Lisbon, 18 March 2014), according to which there exists in Portugal a gap between the importance assigned by citizens to democratic institutions and how they assess the performance of those institutions. This is especially true, for instance, with regard to such topics as the functioning of the courts and the fight against poverty and social inequalities.

\section{A New Cycle of Demonstrations in Portugal and Southern Europe}

This is the background against which we should analyze the sociological factors underlying the wave of demonstrations that took place in Portugal between 2011 and 2013. At the global level, the various events of the latest cycle of rebellions share the following common traits: they are definitely driven by educated young people and disseminated through cyberspace, as mentioned above, they have a flexible, network-type of organization, no identifiable leaders, and they are partly spontaneous. Because of media exposure - mainly

\footnotetext{
${ }^{15}$ The data relate to the private sector alone. Source: DGAEP - Directorate General for Administration and Public Employment, 2014.
} 
through cyberspace - the images and the engrossing spectacle of the rebellious masses as well as the collective celebration of victorious outcomes are bound to produce a mimetic effect leading to a rapid international spread.

On 12 March 2011 no one expected so many people to show up for the first big Geração à Rasca $^{16}$ demonstration. Public discontent with the political parties and representative democracy was plainly visible. Among many others, slogans such as the following were widely heard in Lisbon and Porto: "precarious is what you want, rebels is what you get!", "we want our lives!"; "wage theft!"; "the country is in distress!"; "enough with the trashy economy!"; "casual workers are no suckers!"; "the people united have no need for parties!"; "precariousness is what's trashy"; "do not make me emigrate"; "I want to be happy"; and "who elected the markets?" One newspaper covering the event stated: "Protest also marked by posters with the word 'flexitanga' ${ }^{17}$ and red carnations. [...] Television images show a sea of people on Avenida da Liberdade" (Expresso, 12 March 2011). According to the organizers, there were about 200,000 marchers in Lisbon and 80,000 in Porto.

That was a high point in Portuguese protest movements - actually it was a turning point, in that the trade union field ceased to have a monopoly on social and labor action, which perhaps helps explain the prominence given to the whole issue in the public agenda at the time. Two months later, the Indignados and the Acampadas (or encampments) of Democracia Real Ya, in Madrid's Puerta del Sol square, sent a similar message while invoking the Portuguese precedent (Velasco, 2011). Right after that there was the global wave of protests around the Occupy Wall Street movement, which centered in New York City but soon spread worldwide (Taylor et al., 2011; Harvey et al., 2012). Portugal witnessed the unfolding of the following cycle of events, here listed in chronological order: 15 October 2011 (Global Action Day); the general strike of 24 November 2011 (co-organized by the two main trade union confederations, CGTP and UGT); the 12 May 2012 gatherings (Global Spring); 15 September 2012 (Screw Troika); 13 October 2012 (culture-related protests by the movement of artists associated with Screw Troika); the European-wide general strike on 14 November 2012 (held in Portugal, Greece, Spain, Malta and Cyprus); in 2013, the 3 March

\footnotetext{
${ }^{16}$ Literally, a "Generation in distress," which plays on a previous, almost identical, slogan - Geração rasca ("Trashy Generation"). The following are also more or less free adaptations of other slogans from the same context. [TN]

${ }^{17}$ The word tanga - a loincloth - can mean both destitution and sham. The red carnations are a symbol of the April 1974 Revolution. [TN]
} 
demonstration (inspired by the popular song Grândola Vila Morena, o Povo é Quem mais Ordena - "Grândola, swarthy town where the people reign supreme"), followed by a wave of actions promoted by organized groups of young people, the "Grandoladas," which included the boycotting of formal events attended by government officials whose speeches were shouted down with lines from that song or disrupted by collective laughter, their main target being former cabinet minister Miguel Relvas (Soeiro, 2014).

We should look beyond these peaks of tension (which in fact had first been felt during José Sócrates's government) and go back at least a decade to trace the beginning of the collapse of many of the illusions nurtured by the Portuguese middle class. Back, that is, to the successive, cyclic, corporatist union mobilizations, strikes and labor conflicts led mainly by those socio-economic sectors of the "middle class" whose members - teachers, civil servants, doctors, nurses and other health workers - formed the backbone of trade unions, after the old working class increasingly lost its pull and pugnacity and unionism became more and more institutional and bureaucratic. However, the latest wave of protests not only resumed the world of labor as its primary cause, but also gave a new impetus to collective action in this area (Estanque, Costa and Soeiro, 2013).

\section{Brazil: The Middle Class, the Labor Market, and the Safeguarding of the Political System} With the advent of the new millennium, particularly after 2003, Brazilian indicators with respect to the labor market and the economy began to improve. On average, the rate of economic growth was 5.4\% until 2008 and 5.5\% in the years 2009 and 2010 . Wages, on the other hand, continued to rise faster than inflation (Krein and Baltar, 2013). Arguably the extension of the Bolsa Familia program (or "family grant"), together with the real increase in the minimum wage and with subsidized popular credit, combined with economic growth to help strengthen the labor market and increase consumption. Between 2003 and 2010, 2.1 million formal jobs were created per year on average, the overwhelming majority of which in the service sector. This was to lead to the growing use, in the media, of an exultant, recurrent discourse on the growth of the "new middle class," applauded by some and criticized by others (Pochmann, 2012; Bartelt, 2013). 
Based on official criteria, ${ }^{18}$ in the year 2000 this Brazilian "middle class" - as measured by household income and consumption - comprised $31.7 \%$ of households, while its consumption capacity was estimated at $50 \%$ of Brazil's entire consumer market. According to a study by Datafolha, in 2012 its various strata (upper-middle class, middle-middle class and lower-middle class) ${ }^{19}$ totalled $63 \%$ of the working population. However, although it is clear that there was a purchasing power increase in the lower and middle strata of the Brazilian social pyramid, such a conclusion is misleading. The studies carried out by Marcelo Neri (2012) for the Getúlio Vargas Foundation (FGV) and IPEA ${ }^{20}$ are imbued with a discourse that openly advocates consumerism and the virtues of marketing and debt, while confusing "social classes" with income categories, as I just pointed out. ${ }^{21}$ The material infrastructure and specific conditions of the quality of life of families (in terms of health, comfort, education, health care, etc.) are not seen as relevant in these typologies.

While it is true that the Brazilian social pyramid has renewed itself, it did so by maintaining job precariousness and instability (Pochmann, 2012: 38). In addition, the turnover rate (c. $37 \%$ of formal jobs, in 2009 ) rose significantly, especially with regard to lowpaying jobs (85.3\% for workers earning up to 2.5 times the minimum wage), with younger workers exhibiting the highest percentages. The purchasing power of these cohorts has improved, their rights have been partly recognized, and access to education has also made positive progress; all these factors combined to promote citizenship and to reinforce aspirations both at the personal and family level.

Social variables are inseparable from the political sphere, therefore it is important to call attention to other specificities of Brazil's young democracy that will help us comprehend the

\footnotetext{
${ }^{18}$ The official definition of middle-class is based on the traditional A, B, C, D, E scale, which was first established by the Secretariat of Strategic Affairs of the Presidency of the Republic (SAE). The sole criterion is that of income level, with the middle class corresponding to people in households whose monthly per capita income ranges from $\mathrm{R} \$ 291.00$ to $\mathrm{R} \$ 1,019.00-$ i.e., $54 \%$ of the population. Hence the following subdivisions: lowermiddle class, with a per capita income between $R \$ 291$ and $R \$ 441$; middle-middle class, earning from $R \$ 441$ to $R \$ 641$; and upper-middle class, whose income may go from $R \$ 641.00$ to $R \$ 1,019.00$. (NB: As of 06.05.2014, the exchange rate between the euro and the Brazilian real is $1 \mathrm{EUR}=3.10 \mathrm{R}$ ).

${ }_{19}$ According to the research in question, between 2001 and 2011 the various strata that make up Brazilian society - based, in this case, on a typology where household income is combined with education and consumption patterns - evolved in the following manner: upper class $10 \%$ to $9 \%$; upper-middle class $17 \%$ to $19 \%$; middle-middle class $17 \%$ to $26 \%$; lower-middle class $23 \%$ to $18 \%$ (Folha de São Paulo, special supplement, 22 January 2012).

${ }^{20}$ The Institute for Applied Economic Research (IPEA) is a federal public foundation linked to the Secretariat of Strategic Affairs of the Presidency of the Republic.

${ }^{21}$ See "O politburo ortodoxo" ("The Orthodox Politburo"), in Carta Capital No. 772, 30 October 2013, pp. 3637 , where the abovementioned expert is described as one of the most prestigious representatives of the neoliberal paradigm in the PT Cabinet.
} 
public protests. The social and trade union movements that marked the 1980s took popular revolt to such extremes that even the promise of a Western-style representative democracy no longer seemed enough to bring reassurance to the Brazilian people. Confronted with the collective strength of the working class, the Brazilian political system felt the need to create safeguard mechanisms with a view to generate parliamentary majorities capable of withstanding the "voice of the street," which in turn led to a strategy of "unnatural" alliances among a wide variety of political parties. That was the system's response to the public demonstrations that led to the impeachment of President Fernando Collor de Melo back in 1990-1991. But there was a point where all this momentum seemed to threaten the legitimacy of Parliament, and that alarmed the ruling elite. A pattern of covert negotiations thus started to emerge, ranging from the mere exchange of favors (and the exchange of votes across "rival" benches) to more serious forms of corruption and promiscuity. Commentators like Mark Noble termed such practices "pemedebismo," after the name of the party - the PMDB - that first resorted to them. ${ }^{22}$ What we have here is the Centrão (or "Big center") principle, devised after 1993 to reinforce the "arc" formed by the potential governing parties. The whole process evolved and was fully in place under President Fernando Henrique Cardoso's governments, ${ }^{23}$ but after spending a decade fighting pemedebismo, the PT (Workers' Party) itself followed the same steps after the Mensalão vote-buying scandal broke in 2005. "Haunted by the specter of impeachment, Lula adopted the pemedebist notion of building parliamentary supermajorities and for that purpose he

\footnotetext{
${ }^{22}$ The PMDB - Brazilian Democratic Movement Party - is the direct heir to MDB (the Brazilian Democratic Movement), first established in 1965-1966 and the main force of democratic opposition during the military dictatorship. The former MDB was already known for its enormous ability to bring together people from the most diverse ideological camps, but today's PMDB (established in 1980) embraced its reputation as a big-tent party and took it even further, hence its nickname "partido pega-tudo" - literally, the "catch-all party."

${ }^{23}$ In 1986 the PMDB promoted the Democratic Alliance that got Tancredo Neves elected and led to a majority in the National Constituent Assembly (based on an agreement with the PFL - Liberal Front Party). That moment represented the consolidation of the Centrão rationale, aimed at neutralizing popular demands: "On the one hand, this process showed that the streets wanted to regain power, which was felt to have been usurped and misused. On the other hand, the political system was sent into something of a panic. Let us keep in mind the fact that we had a 'lukewarm' transition to democracy, negotiated among the elites. At the time of the impeachment, those elites who negotiated the transition 'said: 'How can we protect ourselves against this, because it is just not possible to have a situation where the people take to the streets and remove our presidents from office every time they mess up.' [...] Thus was born the myth of 'super-majorities', i.e., that in order to stay in power and avoid impeachment, governments need to build not only majorities, but supermajorities of upwards of three-fifths of the popular vote, as required in the case of constitutional reforms. This way the political system could go on operating as usual, while presidents, by virtue of the fact that the elected governments would inevitably be bound by the super-majority, would be forced to make a pact with that system" (Nobre, 2013b: 9; cf. Nobre, 2013a).
} 
developed safeguard tools which were to be used in an even more overt manner after 2011, during Dilma Rousseff's presidency" (Nobre, 2013b: 12-13).

\section{The June 2013 Social Rebellions}

At the root of the June demonstrations there were of course multiple causes that can be traced to a number of forces and interconnections located at various levels of analysis, from local context to the state, national and global scale. Earlier in the month the situation in São Paulo (SP) had begun to deteriorate when, as a result of the city's decision to raise the cost of urban transport (from $\mathrm{R} \$ 3.00$ to $\mathrm{R} \$ 3.20$ ), the young members of the Free Pass Movement (MPL) called demonstrations in the city center against the decision. The immediate outcome came in the form of police violence accompanied by statements from the local authorities, who accused the protesters of acting like "vandals" and threatened not to give in. Those two factors - violence and the ill-considered statements made both by the Mayor (PT's Fernando Haddad) and the state Governor (Geraldo Alckmin, PSDB), in a context where the colossal investment in the construction of football stadiums for the 2014 World Cup had already stirred popular discontent - helped trigger the protests that swept Brazil in June and July 2013. The MPL claims soon led to the fight against "corruption" and to demands for "political reform" as well as quality systems of public health and education - in other words, for "FIFA-type standards" of health and education, as shouted in the streets at the time.

On 13 June São Paulo's Avenida Paulista was the site of the first major demonstration. According to Datafolha, ${ }^{24}$ the vast majority of marchers (76\%) were either elementary school or secondary shool graduates. But four days later, on 17 June, there were mostly university students $(77 \%)$, compared to just $22 \%$ protesters with a secondary education - rallying in Largo da Batata. On 17 June, 71\% of protesters were first time participants in a public demonstration, a very telling sign of the massive presence of young people in the protests. Still according to the Datafolha survey, in the 20 June demonstrations, the overwhelming majority of demonstrators (78\%) were young people with some connection to higher

\footnotetext{
${ }^{24}$ The following sources have been used: Datafolha, with surveys conducted by technical staff from the Folha de S. Paulo newspaper on various demonstrations held in June (16, 18 and 20) and on 20 July; the Brazilian Institute of Public Opinion and Statistics (IBOPE) and the Clave de Fá polling company, based on a sample of about 2000 respondents. For the research in question, "IBOPE Intelligência" interviewed 2002 marchers in eight Brazilian cities (São Paulo, Rio de Janeiro, Belo Horizonte, Porto Alegre, Recife, Fortaleza, Salvador and the Federal District) on 20 June. The margin of error is two percentage points and the confidence interval is $95 \%$. Accessed 3 December 2014 at http://www.ibope.com.br/pt-br/noticias/Paginas/89-dos-manifestantes-nao-sesentem-representados-por-partidos.aspx.
} 
education (mostly from the private sector), while $20 \%$ had a secondary education; with regard to age groups, $81 \%$ were aged under 36 . These two indicators strike me as clear proof of the presence of segments of a young, educated, emerging middle class, even if the link to the world of labor and to peripheral residential neighborhoods hints at strong connections to a more qualified, albeit more precarious, working class that is rapidly reshaping itself at present.

The provenance of participants by area of residence also varied over time: while in the first São Paulo demonstration (13 June) there was a majority of 38\% residents from the city's (poorest) East zone, against 32\% from the South zone and 10\% from the West zone (both of them inhabited by the affluent, upper middle class), on 17 June, just a few days later, most participants $-30 \%$ - were residents of the West zone, followed by $26 \%$ from the South zone and a mere $12 \%$ from the East zone. It seems obvious that the tendency toward mass protests went hand in hand with an increase in the number of young people whose social strata are closer to the lifestyles and values of those sectors of the middle-class that tend to be less politicized and more "individualistic" (curiously enough, this happened exactly on those days in which there was evidence of violence against leftist demonstrators and some of their symbols). In other words, as the wave of protests increased in scope and vigor, it was more and more influenced by conservative forces (mostly those opposing social policies) coming from the "established middle class" and the media.

\section{Chart 2. Demonstrations - 20 June 2013, São Paulo}
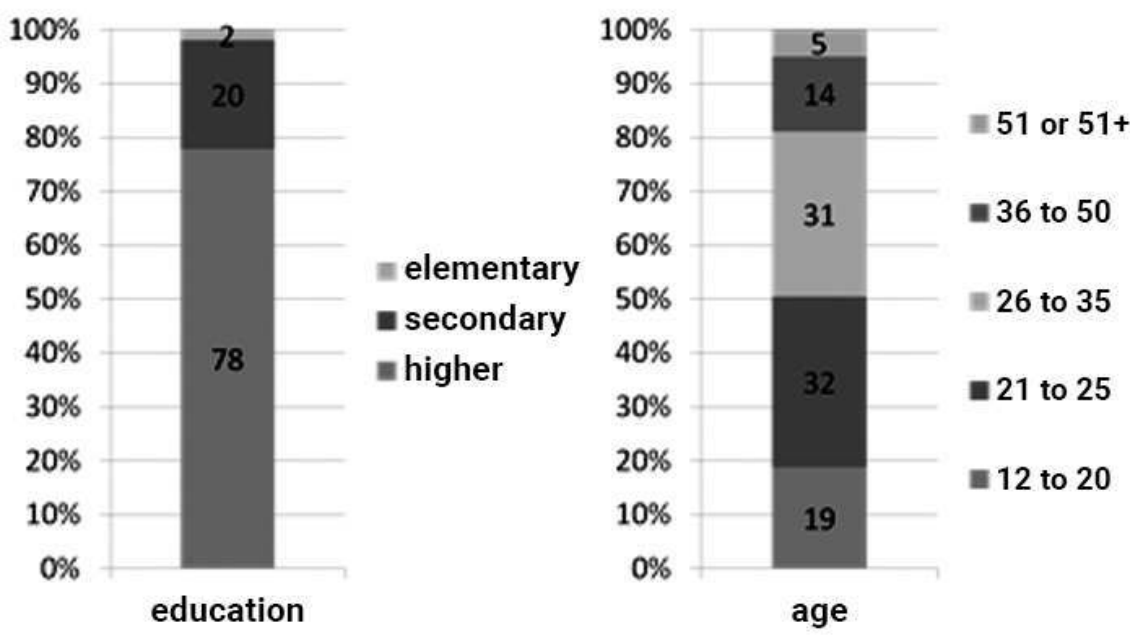

Source: Datafolha (see also the CNI-IBOPE survey dated July 2013, available at http://www.ibope.com.br/pt-br/noticias/Documents/CNI IBOPE edicao\%20especial jul2013 web.pdf). 
This is also confirmed by the polls conducted during that period (Datafolha, 27-28 June and 11 September 2013), which show that São Paulo residents were largely sympathetic to the protesters and that even in the course of the next few months, up until September, a favorable attitude prevailed among the city inhabitants (with $61 \%$ in June and $52 \%$ in September). Those respondents subscribed to the view that the demonstrations "brought more benefits than harm," which only proves the abovementioned attempt, on the part of some sectors on the right, to "instrumentalize" the protests (Datafolha polls, 18 and 21 June, and 11 September). Finally, it should be added that mobilization relied mainly on Facebook (62\%) and other internet-based channels (29\%).

As far as subjectivities, means and motives are concerned, one could say that in this era of virtual communications there exists a materiality of immaterial relationships, which we can see reflected in these events. Communities based on physical proximity and interaction increasingly tend to mix with the networks of the electronic world, where the use of ipods, tablets, computers and mobile phones operates like a web of multiple meanings and (part real, part fictitious) groups of self-identification and "belonging," which are either replacing or complementing the bonds of primary sociability. The connection to the virtual networks is at once an enabler of collective inclusion and a means of personal affirmation and performance, where one's constructed "self," once projected onto the "virtual other," mixes and reshapes itself into the mask that best seems to fit each nook and turn of the vast virtual-real community. The significance of participating in the manif[estation] is expressed in the myriad images, photos and videos captured and disseminated in real time on Facebook and other media (including television). Here the entire aesthetics of adornment, the colors of the improvised poster or the outline of a mask become the simulacrum of a heroic, radical act upon which, in one single gesture, the "I" and the "we" (fleeting though they be) are inscribed. The streets and squares of São Paulo and Rio de Janeiro (RJ) served as a unique setting for these actions, which were of a social as well as political, collective, anonymous or aesthetic nature all at once, but where in the end the social struggle came down to the subject's desperate search for her/himself.

The overwhelming majority of participants in all the demonstrations held in São Paulo during this period identified themselves as workers. As shown in Chart 3, the demonstrators in Rio de Janeiro and the eight state capitals (see footnote 24, above) included a considerable number of young workers with some sort of link to the labor market $(70.4 \%$ in 
the first sample and $76 \%$ in the second one). Of these, respondents belonging to households earning up to twice the minimum wage (MW) accounted for $34.3 \%$ in Rio de Janeiro and $15 \%$ in the combined eight state capitals. As to the strata where household income is above that level, on 20 June households earning 2 to $5 \mathrm{MW}$ represented $30 \%$ of the IBOPE sample (eight capitals) and $54.1 \%$ of the RJ protesters. In short, about half the protesters belonged to families whose average income is less than $5 \mathrm{MW}$ (about $\mathrm{R} \$ 3,800.00$ - i.e., 1,225.00 euros), with a significant portion (35\% of the RJ marchers on 20 June) coming from families who earn up to $2 \mathrm{MW}$.

Chart 3. Protesters, 20 June 2013 - Income
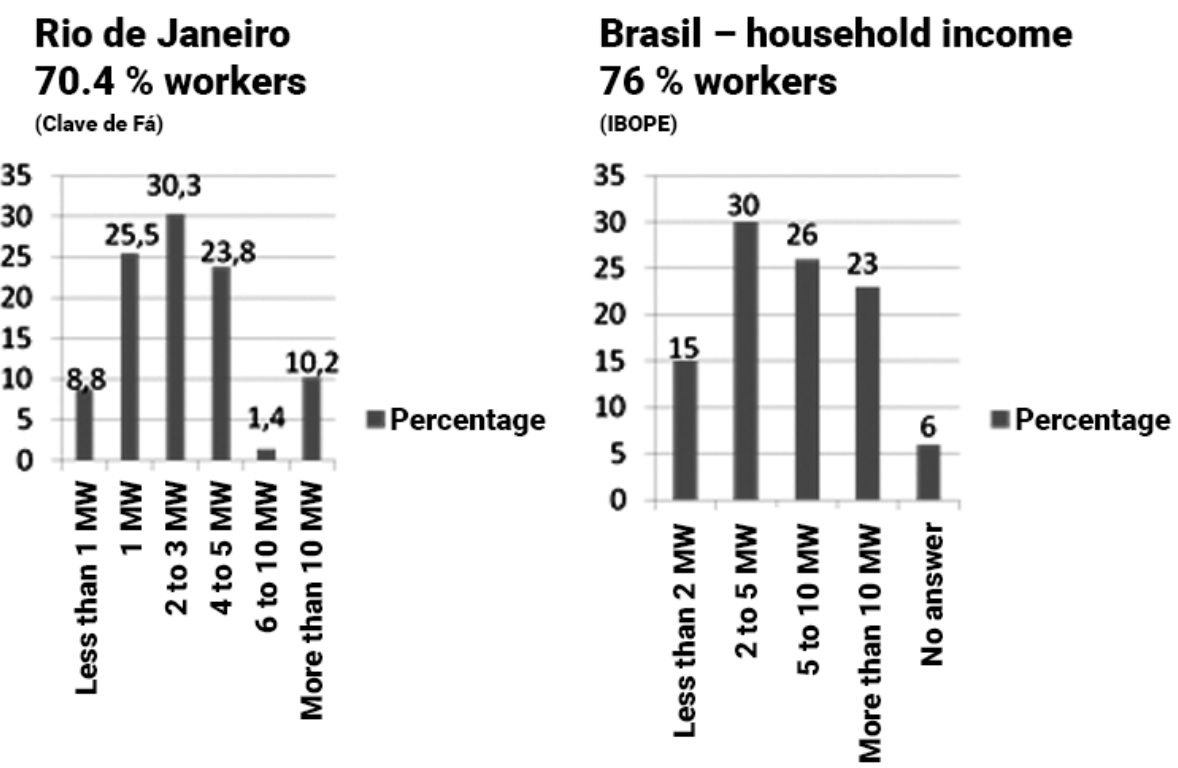

Source: IBOPE/ Clave de Fá, 23 June 2013 (see footnote 22, above).

If we consider the sum total of demonstrators who rallied in the eight state capitals, however, about 23\% came from households with income levels above $10 \mathrm{MW}(\mathrm{R} \$ 6,800.00$, or 2,193.00 euros), although (according to the poll conducted by Clave de Fá) in RJ the representation of households from this particular income group was no more than $10.2 \%$. Although there is no evidence of a solid, well defined middle-class basis, it does seem clear that what we have here are social fringes in the process of distancing themselves from the reference groups they have left behind - i.e., the proletarianized generations from which they largely originate. Moreover, the overwhelming majority of demonstrators were not 
formally affiliated with any political parties (96\%) or trade unions (86\%) (which only goes to prove that they did not belong to the industrial working class either). ${ }^{25}$

As we know, the demonstrations had a huge impact both in Brazil and abroad. In a formal statement that was broadcast live on Brazilian television, President Dilma Rousseff admitted that the demonstrations "show the strength of our democracy and the desire of our youth to move Brazil forward. If we make good use of the momentum brought by this new political energy, we can, in better and faster ways, achieve a lot of what Brazil has so far been unable to conquer" (President Dilma Rousseff's National Address on 21 June 2013 - TV Globo). But that did not prevent (in the short term at least) an abrupt loss of trust on the part of the electorate with regard to the country's institutions and social players, as evinced by a simple comparison of the 2012 results with those of July 2013, after this cycle of rebellions was over. According to a number of IBOPE opinion polls, the fall in the approval rating affected mainly the following aspects: Presidency of the Republic - from $63 \%$ to $42 \%$; the public health system - from $42 \%$ to $32 \%$; the Federal Government - from $53 \%$ to $41 \%$; the National Congress - from $36 \%$ to $29 \%$; the trade unions - from $44 \%$ to $37 \%$ (IBOPE, 31 July 2013).

\section{In Conclusion}

The cycle of public protests that swept the world over the past three years was accompanied by such a rich variety of factors and of political and socio-cultural contexts, by so many levels of social awareness and activist engagement, that it becomes difficult to find points of comparison amidst such widely dispersed phenomena. But this interconnected world of ours builds unlikely links that transcend geography. In their incessant circuits, these connections keep changing as they move on ever-renewed channels that link the real and the virtual and that in practice are bound to affect particular groups in terms of their symbolic structures and logics for action.

Youth and precariousness have been at the center of these reflections, whether it's in the struggles of precarious workers in Portugal and Southern Europe, or in the Brazilian uprisings of June 2013 - even if in the latter case there were few explicit allusions to labor issues. The young people under analysis are schooled, very familiar with the new social networks, and on a trajectory that is either heading toward the middle class or under the influence of

\footnotetext{
${ }^{25}$ Besides, it is a known fact that the Brazilian trade union structures were caught off guard by these events and more or less accused them of being manipulated by the right and the media.
} 
middle-class lifestyles and consumption patterns. While, on the one hand, educational resources, job security and access to credit have made it possible to move closer to the intermediate rungs of the social ladder, on the other hand we have situations where (especially in the Portuguese case) people's economic resources and living conditions suffered the impact of the austerity measures, or where (especially in Brazil) social conditions, government policies and public infrastructures have deteriorated to the point of thwarting the consolidation of fundamental rights and opportunities.

In their most radical moments, these mobilizations have brought to the fore the political and symbolic power inherent in collective struggles and outbreaks of public anger. At the same time, however, they have unveiled an individualistic bent whose signs became visible in the very midst of the crowds during the protests. This ambivalence between the individual and the group was felt in the larger rallies held in Portugal (and also among the Spanish Indignados, for example), as collectivist discourse and expressions of solidarity could be heard alongside the more individualistic slogans ("I want to be happy"), and the demands for more democracy were displayed side by side with an "anti-politics" stance and the repudiation of democracy's values and institutional agents ("the people united have no need for parties!").

One might say that the contradictory meanings of these processes are articulated in two very different ways: through a dynamics of rebellion, which expresses the indignation of a casualized working class, but also, and somewhat paradoxically, through individual performance and the latent signs of consumerism, which convey a middle-class ethos. Such ambivalent tendencies highlight the complexity of a situation where there is, on the one hand (in the case of Brazil), growing social awareness among those who claim the rights, opportunities and dignity they never had, and on the other (especially in Portugal), growing frustration and despair at seeing one's long-recognized rights being suddenly revoked by the diktats of economic might and a discredited political power.

By emphasizing the middle-class drive that seems to be a hallmark of this cycle of protests, I do not mean to play down the political and even emancipatory potential of the struggles. In fact, the deep social turbulence and the radicalism evident in some of them can serve as ingredients for building new identities, in which many emotionally intense, high-risk experiences are forged that may prove capable of reinforcing cultures of resistance, bonds of solidarity and the ability to break away from institutions and powers hitherto viewed as 
unassailable. In Southern Europe and Brazil alike, the working class has gone through a rapid process of recomposition and segmentation. Therefore, when I stressed the notion of a "middle class" my purpose was not so much to invoke a substantive player as to suggest a different way of conceiving of the transformations under way in the world of labor and collective action.

The Brazilian working class - namely its younger, schooled segments - is heir to a destitute condition that until only recently has kept it tied down to dependencies and prejudices going back to the times of slavery and colonialism. It was not until the last decade that we saw the first glimpse of emancipation, with remarkable progress being made in terms of the recognition of rights and access to social entitlements, which however were accompanied by the emergence of new, vulnerable and precarious - albeit better educated - segments. Although not belonging to a de facto middle class, these new socio-occupational strata are part and parcel of a trajectory that is being redefined as a consequence of the fact that (given the blatant asymmetry between educational resources and economic standing) their status has been "truncated" and marked by insecurity. In short, we are dealing here with a segment that is quite different from the more adjusted, "traditional" layers of the middle class as well as more prone to radicalization. At the same time, however - this is my contention - it constitutes neither a vanguard nor a new voice of the working class or the lower classes as a whole.

In the European context, and in Portugal in particular, the "middle class effect" unfolded under a double logic: first of all, because the outbreaks were largely caused by the contraction of the welfare state, which had been the main "escalator" of the salaried middle class; and second, because in Southern Europe, too, the dynamics of the youth who rallied in the "non-organic" demonstrations and the "acampados" voiced the rage and the rebelliousness of those segments that had more schooling, better qualifications and greater familiarity with the new networks and platforms of online activism. That there was a pervasive desire to stand up for social cohesion and justice was something that became all too obvious, while at the same time there was clearly also a latent sense of personal dissatisfaction with a consumerist dream that had been either left unfulfilled or unexpectedly cut short.

While stability and predictability in everyday life are salient features of the "middle-class" habitus, a precarious condition is the exact opposite of that. One could say that in the 
Brazilian case the "middle class" ${ }^{26}$ is a construct (perhaps even a mirage), while in the Portuguese case it has become a descent into purgatory for those who thought themselves at the gates of paradise. Whether in the future these phenomena are yet to grow or fade away is something that depends on the severity of the constraints currently afflicting the welfare state, on democratic institutions and global capitalism, as well as on their own strength and on the ability to reinvent themselves. These movements are certainly not expected to generate the rebirth of a new hyper-subject, the would-be protagonist of the twenty-first century's "redemptive" revolution. But the current recomposition of the working class and the precariat, together with the reshaping of the economy's structural antagonisms and the role played by the new media and communication networks, open up whole new horizons in terms of new arenas and modalities of activism. Mass rebellions are taking new shapes, but the old tension between alienating consent and the raising of political awareness is far from over.

Translated by João Paulo Moreira

Revised by Teresa Tavares

\section{References}

Adamovsky, Ezequiel (2013), “'Clase media': reflexiones sobre los (malos) usos académicos de una categoria," Nueva Sociedad, 247: 38-49.

Antunes, Ricardo (2013), Os sentidos do trabalho. Coimbra: Almedina.

Arcary, Valério (2013), "Até onde vamos aguentar?" Interview published on Blogue de Leituras Raquel Varela, 30 October 2013. Accessed on 24.03.2013, at https://raquelcardeiravarela.wordpress.com/2013/10/30/ate-onde-vamos-aguentar/.

Barker, Colin (2008), "Some Reflections on Student Movements of the 1960s and Early 1970s," Revista Crítica de Ciências Sociais, 81: 43-91. DOI : 10.4000/rccs.646

Bartelt, Dawid Danilo (ed.) (2013), A 'nova classe média' no Brasil como conceito e projeto político. Rio de Janeiro: Fundação Heinrich Böll Stiftung.

Boltanski, Luc; Chiapello, Ève (2001), Le nouvelle esprit du capitalisme. Paris: Gallimard.

Bourdieu, Pierre (1979), La distinction. Critique sociale du jugement. Paris: Seuil.

Burawoy, Michael (2009), O marxismo encontra Bourdieu. Campinas: Editora da Unicamp.

Braga, Ruy (2012), A política do precariado: do populismo à hegemonia lulista. São Paulo: Boitempo.

\footnotetext{
${ }^{26}$ Meaning, in this context, the new, emerging segments of young wage earners with high educational capital, and in the case of Portugal, the stable sectors associated with the old type of "safe" employment and civil servants.
} 
Cantante, Frederico (2013), "A magreza das classes médias em Portugal," in Renato Miguel do Carmo (ed.), Portugal uma sociedade de classes: polarização social e vulnerabilidade. Lisboa: Edições 70/Le Monde Diplomatique, 129-150.

Carmo, Renato Miguel (ed.) (2013), Portugal uma sociedade de classes: polarização e vulnerabilidade. Lisboa: Edições 70/Le Monde Diplomatique.

Cohen, Jean L.; Arato, Andrew (1994), Civil Society and Political Theory. Cambridge: MIT Press.

Dallinger, Ursula (2011), "The Endangered Middle Class? A Comparative Analysis of the Role Public Redistribution Plays," Luxembourg Income Study - Working Paper Series, no. 565. Accessed on 20.12.2013, at http://www.lisdatacenter.org/wps/liswps/565.pdf.

Eagleton, Terry (2003), After Theory. New York: Basic Books.

Eder, Klaus (2001), "A classe social tem importância no estudo dos movimentos sociais?," Revista Brasileira de Ciências Sociais, 16(46): 5-27.

Engels, Friedrich (2009), The Condition of the Working Class in England. Oxford World's Classics. Oxford: OUP [orig. ed.: 1845].

Erikson, Robert; Goldthorpe, John (1992), Constant Flux: A Study of Class Mobility in Industrial Societies. Oxford: Clarendon Press.

Esping-Andersen, Gøsta (ed.) (1996), Welfare States in Transition. National Adaptations in Global Economies. London: Sage.

Estanque, Elísio (2003), "O efeito classe média - Desigualdades e oportunidades no limiar do século $\mathrm{XXI}$," in Manuel Villaverde Cabral; Jorge Vala; André Freire (eds.), Percepções e avaliações das desigualdades e da justiça em Portugal numa perspectiva comparada. Lisboa: ICS, 69-105.

Estanque, Elísio (2012), A classe média. Ascensão e declínio. Lisboa: Fundação Francisco Manuel dos Santos/Relógio d’Água.

Estanque, Elísio; Bebiano, Rui (2007), Do activismo à indiferença - Movimentos estudantis em Coimbra. Lisboa: ICS.

Estanque, Elísio; Costa, Hermes Augusto (2011), O sindicalismo português e a nova questão social Crise, consolidação ou renovação? Coimbra: CES/Almedina.

Estanque, Elísio; Costa, Hermes Augusto; Soeiro, José (2013), "The New Global Cycle of Protest and the Portuguese Case," Journal of Social Science Education, 12(1): 31-40.

Estanque, Elísio; Mendes, José Manuel (1997), Classes e desigualdades sociais em Portugal - um estudo comparativo. Porto: Afrontamento.

Ferreira, António Casimiro (2012), Sociedade da austeridade e direito do trabalho de exceção. Porto: Vida Económica.

Guimarães, António Sérgio (2002), Classes, raças e democracia. São Paulo: Editora 34.

Harvey, David et al. (2012), Occupy. Movimentos de protesto que tomaram as ruas. São Paulo: Boitempo/Carta Maior.

Huws, Ursula (2003), The Making of a Cybertariat: Virtual Work in a Real World. New York: Monthly Review Press.

Krein, José Dari; Baltar, Paulo Eduardo (2013), "A retomada do desenvolvimento e a regulação do mercado do trabalho no Brasil," Cadernos CRH, 26(68): 273-292.

Laclau, Ernesto (1996), Emancipation(s). London: Verso. 
Lenin, V. I. (1972), "A Great Beginning: Heroism of the Workers in the Rear. 'Communist Subbotniks'," in Collected Works, Vol. 29. Moscow: Progress Publishers. Available at https://www.marxists.org/archive/lenin/works/1919/jun/28.htm.

Marx, Karl (1967), Capital. Critique of Political Economy. Vol. III, Ch. 52. New York: International Publishers. Available at https://www.marxists.org/archive/marx/works/1894-c3/ch52.htm.

Melucci, Alberto (2001), A invenção do presente. Rio de Janeiro: Vozes.

Neri, Marcelo (2012), A nova classe média: o lado brilhante da base da pirâmide. São Paulo: Fundação Getúlio Vargas/Editora Saraiva.

Nobre, Marcos (2013a), Choque de democracia - Razões da revolta. São Paulo: Companhia das Letras.

Nobre, Marcos (2013b), Interview, Jornal da Unicamp, 28 July 2013. Accessed on 19.12.2013, at http://www.unicamp.br/unicamp/ju/567/revoltas-decretam-o-fim-do-ciclo-de-redemocratizacaodiz-docente.

Nunes, Nuno (2013), Desigualdades sociais e práticas de ação coletiva na Europa. Lisboa: Editora Mundos Sociais.

Pais, José Machado (1990), "A construção sociológica da juventude," Análise Social, 105/106: 139-165.

Parkin, Frank (1968), Middle Class Radicalism. Manchester: Manchester University Press.

Parkin, Frank (1979), Marxism and Class Theory: A Bourgeois Critique. London: Tavistock. DOI : $10.2307 / 40182929$

Pochmann, Márcio (2012), Nova classe média? O trabalho na base da pirâmide social. São Paulo: Boitempo.

Pinto, António Costa; Sousa, Luís de; Magalhães, Pedro (eds.) (2013), A qualidade da democracia em Portugal. Lisboa: Editora do ICS.

Santos, Boaventura de Sousa (2003) (ed.), Democratizar a democracia: os caminhos da democracia participativa. Porto: Afrontamento.

Santos, Figueiredo José Alcides (2004), Estrutura de posições de classe no Brasil: Mapeamento, mudanças e efeitos na renda. Belo Horizonte: Editora da UFMG.

Savage, Mike et al. (2013), "A New Model of Social Class? Findings from the BBC's Great British Class Survey Experiment," Sociology 47(2): 219-50. DOI : 10.1177/0038038513481128

Soeiro, José (2014), "Da Geração à Rasca ao Que se Lixe a Troika. Portugal no novo ciclo internacional de protesto," Sociologia: Revista do Departamento de Sociologia da FLUP, XXVIII, available at http://ler.letras.up.pt/site/default.aspx?ary=id04id111\&sum=sim.

Souza, Jessé de (2010), Os batalhadores brasileiros: nova classe média ou nova classe trabalhadora? Belo Horizonte: Editora da UFMG.

Standing, Guy (2009), Work after Globalisation: Building Occupational Citizenship. Cheltenham: Elgar.

Standing, Guy (2013), O precariado. A nova classe perigosa. São Paulo: Editora Autêntica.

Standing, Guy (2014), "O precariado e a luta de classes," Revista Crítica de Ciências Sociais, 103 (May). DOI : 10.4000/rccs.5521

Taylor, Astra et al. (eds.) (2011), Occupy. Scenes from Occupied America. London: Verso.

Touraine, Alain (1985), "An Introduction to the Study of Social Movements," Social Research, 52(4): 749-788. 
Touraine, Alain (2006), "Na fronteira dos movimentos sociais," Sociedade e Estado, 21(1): 17-28. DOI: 10.1590/S0102-69922006000100003

Thompson, E. P. (1966), The Making of the English Working Class. New York: Vintage [orig. ed.: 1963].

Velasco, Pilar (2011), NO Nos Representan. El Manifesto de Los Indignados en 25 Propuestas. Madrid: Ediciones Planeta Madrid S.A.

Žižek, Slavoj (2013), "Problemas no paraíso", in Slavoj Žižek et al., Cidades Rebeldes: passe livre e as manifestações que tomaram as ruas do Brasil. São Paulo: Boitempo/Carta Maior, 101-108. 